\title{
Diverging Response to the Rohingya Refugee Crisis since 2017 Military Crackdown: Comparative Analysis of Bangladesh and Malaysia
}

\author{
Yoojeong Jeong
}

In this paper, I examine the diverging responses of neighboring countries in response to the Rohingya Refugee Crisis in order to answer the question of what made Bangladesh more accepting of Rohingya refugees. In light of the existing literature, two tentative explanations are proposed. One concerns the external economic inducement, and the other focuses on the political leeway enjoyed by the incumbent. Drawing on the comparative analysis of Bangladesh and Malaysia, I find support for the political leeway explanation. Bangladesh has accepted the Rohingya refugees as its political leeway allowed the government to turn the crisis to its political advantage. Bangladesh's domestic political environment, including a robust ruling party and a weak opposition party, has ensured the government to dominate the issue framing of Rohingya refugees that benefits the government's position. On the other hand, Malaysia's political environment limited its government's ability to influence the issue framing; facing domestic political opposition, it hardly accepted the Rohingya refugees.

Key Words: Rohingya Refugee Crisis, Rohingya refugees, Bangladesh, Malaysia, humanitarian aid, domestic political environment

\section{INTRODUCTION}

This article seeks to explain the diverging responses of neighboring countries

* Yoojeong Jeong (jjyoo1123@korea.ac.kr) received her M.A. degree from Graduate School of International Studies, Korea University with a focus on International Peace \& Security (IPS).

This work is based on her master's dissertation submitted to Korea University in 2021 and was supported by the BK21 program of the National Research Foundation of Korea.

The author thanks her dissertation advisor Professor Sijeong Lim and her committee members Professor Jae-seung Lee and Professor Seung Hyun Nam for their valuable feedback. The author is also grateful to the editor and three anonymous reviewers for their insightful comments.

The Korean Journal of International Studies Vol.19, No.1 (April 2021), 133-165 
in response to the Rohingya Refugee Crisis. Generally, in the early phase of the regional refugee crisis, host countries with the sudden inflow of refugees are sympathetic and humane towards the refugees (Georgiou and Zaborowski 2017; Yesmin 2016). The host countries express humanitarian concerns to refugees and their country of origin. However, as the situation becomes a protracted refugee situation, the countries' policies towards the refugees gradually become more restrictive (Georgiou and Zaborowski 2017; Yesmin 2016). Likewise, in the Rohingya Refugee Crisis, the neighboring countries of Myanmar, including Bangladesh and Malaysia, gradually changed their stance to close the border and provide only the minimum humanitarian support, especially since early 1990s.

It is interesting, however, to observe that two neighboring countries of Myanmar faced with common regional refugee crisis, Bangladesh and Malaysia, showed different stance since 25 August 2017, the outbreak of military crackdown in Myanmar.

Table 1. Different responses of Bangladesh and Malaysia since 25 August 2017

\begin{tabular}{|c|c|c|c|}
\hline & & Bangladesh & Malaysia \\
\hline \multirow{2}{*}{$\begin{array}{l}\text { Total Number of } \\
\text { Rohingya refugees }\end{array}$} & $\begin{array}{l}\text { As of } \\
\text { January } 2021\end{array}$ & 871,924 & 102,350 \\
\hline & \begin{tabular}{|l|} 
Arrivals after \\
25 August 2017 \\
\end{tabular} & 725,703 & No data \\
\hline \multicolumn{2}{|c|}{$\begin{array}{l}\text { Attempt of repatriation } \\
\text { since } 25 \text { August } 2017\end{array}$} & $\mathrm{No}^{1}$ & $\begin{array}{l}\text { 1,086 people deported }{ }^{2} \\
\text { (Feb 23, 2021) }\end{array}$ \\
\hline \multicolumn{2}{|c|}{$\begin{array}{l}\text { UNHCR's access to the } \\
\text { recently arrived Rohingya refugees }\end{array}$} & $\begin{array}{l}\text { Granted UNHCR's access to } \\
\text { Rohingya refugees }\end{array}$ & Blocked the access since 2020 \\
\hline \multirow{2}{*}{$\begin{array}{l}\text { How host } \\
\text { governments refer } \\
\text { to these refugees? }\end{array}$} & \begin{tabular}{|l|} 
Those with \\
valid documents
\end{tabular} & \multirow{2}{*}{$\begin{array}{l}\text { "Forcibly displaced } \\
\text { Myanmar nationals" }\end{array}$} & "Genuine refugees" \\
\hline & $\begin{array}{l}\text { Those without } \\
\text { valid documents }\end{array}$ & & $\begin{array}{l}\text { "Illegal immigrants" } \\
\text { (send to detention camp and } \\
\text { "impose criminal penalty") }\end{array}$ \\
\hline \multicolumn{2}{|c|}{ How they arrive at the host country? } & By foot & $\begin{array}{l}\text { 1. By boat } \\
\text { 2. Myanmar } \rightarrow \text { Thailand (by foot) } \\
\rightarrow \text { Malaysia (by foot) }\end{array}$ \\
\hline
\end{tabular}

Source: UNHCR (2020a), UNHCR (2020b), UNHCR (2020c), The Star (2017), BBC (2021), Author

${ }^{1}$ A Human Rights Watch report published in August 2018 says, "UNHCR has not recorded a single instance of refoulement [by Bangladesh] during this crisis," and "none of the refugees interviewed by Human Rights Watch said that they felt under any pressure to repatriate (Human Rights Watch 2018a, 41)."

${ }^{2}$ On 23 February 2021, the Malaysian government repatriated 1,086 people who seemingly committed immigration offenses back to Myanmar (BBC 2021). Although the government argues that these people agreed to go back to Myanmar, UNHCR or other international organizations cannot confirm the government's argument due to its lack of access to the detention camp. UNHCR mentioned that "at least six people registered with the organization were among the deportees" (BBC 2021). 
Since 25 August 2017, Bangladesh has opened its border to host Rohingya refugees, allowed them to go through the refugee registration process, and kept them from involuntary repatriation. Malaysia, to the contrary, largely sustained its restrictive stance. To keep the Rohingya refugees from entering the Malaysian border, the government pushed boats full of Rohingya refugees back to sea, but those who reached Malaysia "are being detained and prosecuted for illegal entry into the country" (Human Rights Watch 2020c). Hence, the diverging stances of the two countries raise the question of 'what made Bangladesh more accepting' of Rohingya refugees.'

The comparison of these two countries is interesting due to their common features. Although both countries are prime destinations for Rohingya refugees, they are not bound by international refugee law to legally recognize and protect them (OHCHR 2021). Still, the shared religious faith with Rohingya might draw two Muslim countries' attention to take active action (CIA 2020a; CIA 2020b), such as the active role played by the Organization of Islamic Cooperation (OIC). Since the 2017 military crackdown, Bangladesh has welcomed Rohingya refugees and protected them from refoulement, whereas Malaysia hardly accepted Rohingya refugees. What then explains the more open admission policies towards the Rohingya refugees in Bangladesh than in Malaysia when the two countries' commonalities are considered? I propose two tentative explanations:

1. Countries receiving larger economic incentives in return for accepting refugees are more likely to accept refugees.

2. Governments facing less political competition are more likely to accept refugees.

To preview, I find more consistent support for the second explanation. The diverging responses of Bangladesh and Malaysia are attributable to their distinct domestic political environment. A weak domestic political opposition in Bangladesh allowed the government to insulate itself from the potential backlash against accepting refugees and further allowed the government to control the issue framing for its political benefit.

\footnotetext{
${ }^{3}$ In this paper, accepting Rohingya refugees refers to host incoming refugees and let them go through the refugee assessment process regardless of valid documentation, including identification documents, immigration permit or pass. Also, the host government should allow UNHCR's access to the new arrivals and should not pressure the refugees to repatriate. Moreover, this research is limited to the admission policy that does not include what happens after refugees' admission, including refugees' treatment.
} 


\section{BACKGROUND}

\section{BANGLADESH'S RESPONSE TO THE CRISIS}

Bangladesh has been the primary destination of Rohingya refugees due to its geographic proximity. The first mass inflow of Rohingya refugees entering Bangladesh was in 1978 that about 250,000 Rohingya fled to Bangladesh (Kiragu et al. 2011; Human Rights Watch 2000). Back then, the government was keen to accept Rohingya's mass exodus as a 'humanitarian crisis' (Milton et al. 2017, 2). The government's humanitarian approach has provided refugees with temporary shelters and other support for the refugees, including food and medical services.

After 1992, however, the Rohingya people who fled to Bangladesh were no longer recognized as refugees but identified as 'illegal immigrants' (Milton et al. $2017,2)$, and the government forcibly deported 4 these people while denying UNHCR's access to the refugee camps (Yesmin 2016, 78-9; UNHCR 2013, 12). Diverse factors could explain the shift of the government's stance towards these refugees. ${ }^{5}$ Still, the main reason according to the existing literature is the "protracted refugee situation (Loescher and Milner 2009, 9-10)" of Rohingya Crisis. The refugees would not be staying in Bangladesh temporarily but rather until the long history of state-led persecution comes to an end.

The outbreak of military crackdown in 2017 became the catalyst for Bangladesh to accept the skyrocketing number of Rohingya refugees. Contrary to its previous harsh response, Bangladeshi government has accepted about 725,703 Rohingya refugees after the military crackdown on 25 August 2017; up to 871,924 refugees are in Cox's Bazar district on 31 January 2021 (UNHCR 2020c). Also, there was no single instance of involuntary deportation while granting full UNHCR's access to refugee camps and new arrivals (Human Rights Watch 2018a, 41). In short, since the 2017 military crackdown, the Bangladeshi government's stance is to host the Rohingya refugees and keep the refugees from refoulement.

\footnotetext{
(2013).

${ }^{4}$ For more information on complex dynamics of refoulement back then, please refer to UNHCR

${ }^{5}$ Another possible explanation could be the intricate dynamics of the post-Cold War period and the constant inflow of Rohingya refugees. In the post-Cold War, most developed states became less willing to provide humanitarian aid to support refugee camps (UNHCR 2013, 37). However, approximately 270,000 Rohingya refugees entered Bangladesh from Myanmar in March 1992 (UNHCR 2013, 12). The endless influx of Rohingya refugees, along with the decline in international assistance, might have caused the Bangladesh government to close its border and forcibly deport the refugees.
} 


\section{MALAYSIAN RESPONSE TO THE CRISIS}

Along with Bangladesh, Malaysia is another prime destination for Rohingya refugees for several reasons: "relative proximity, the prospect of jobs in a relatively wealthy country, and shared Islamic faith" (Ehmer and Kothari 2020, 1). Contrary to the expectations of the refugees who risked their lives to reach Malaysia, it does not legally recognize refugees, but rather regard them as "illegal immigrants" (Human Rights Watch 2020b). Malaysia provides minimum humanitarian support to the refugees, only those recognized by the UNHCR (Yesmin 2016, 87).

However, during the 1970s and 1980s, Malaysia had a history of hosting refugees from various countries, including Myanmar, Indonesia, and Bosnia (Mathew and Harley 2014, 11). Malaysia gradually closed its borders to incoming refugees. It adopted the policy of "arrest and detention" when about 8,000 Rohingya refugees fled to Malaysia in 1991 and 1992 (Lewa 2001). After the Asian Financial Crisis, the Malaysian government adopted a harsh policy towards these refugees by deporting illegal immigrants and taking away their work permissions. The government's amendment of the "Immigration Act of 1959/1963 (Kaur 2008, 7-13)" and the adoption of a "zero-tolerance policy (Yesmin 2016, 85)" further deterred the government from accepting refugees and allowed the imprisonment of illegal immigrants. The strict policy continued during the 'boat crisis' since 2012 when the refugees on boats were consistently stranded on the ocean and banned from arriving ashore (Fuller and Cochrane 2015; The Guardian 2015; Al Jazeera 2020).

For Malaysia, the 2017 military crackdown did not work as the catalyst, but it became more restrictive as the situation got protracted. Through the Immigration Act, the government could penalize the arrivals without "a valid immigration pass or permit" by "up to five years in prison, a fine of RM10,000 (US\$2,347.00), and six lashes of the cane ${ }^{6}$ " (Human Rights Watch 2020c). Moreover, a few weeks ago, the government deported Myanmar nationals that would likely include those who suffered from state persecution, according to UNHCR (BBC 2021). Although the government argues that all the deportees voluntarily returned to Myanmar, UNHCR cannot confirm the matter due to its lack of access to the immigration detention camp (BBC 2021). As of January 2021, 102,350 Rohingyas refugees ${ }^{7}$ are

6 On 27 June 2020, 40 Rohingya refugees who reached Malaysian waters without "valid immigration pass or permit" were sentenced to 7 months in prison, and some convicted people "faced three strokes of the cane," which is "brutal punishment that constitutes torture" (Human Rights Watch 2020c; Ahmed and Ratcliffe 2020).

${ }^{7}$ It is important to note that the lower number of Rohingya refugees in Malaysia than Bangladesh is not only caused by the Malaysian government's restrictive policy. Various aspects should be taken 
in Malaysia, while refugee admission policy is becoming more restrictive.

In the following section, I provide two tentative explanations for the diverging stances of Bangladesh and Malaysia in light of existing literature on the determinants of refugee policies.

\section{TWO EXPLANATIONS}

\section{EXPLANATION 1. COUNTRIES RECEIVING LARGER ECONOMIC INCENTIVES IN RETURN FOR ACCEPTING REFUGEES ARE MORE LIKELY TO ACCEPT REFUGEES}

As Rohingya refugees' host countries are mostly developing countries, one of the host governments' primary concerns would be an economic burden. Letting aside the debate on whether the presence of refugees in the long term is an asset or a burden to the host country (Ongpin 2008; Jacobsen 2002; Whitaker 1999; Rutinwa and Kamanga 2003; Alix-Garcia 2007; Vas Dev 2003; Taylor et al. 2016), the prevalent economic concern for host countries is that they would have to share a limited amount of scarce resources with the incoming refugees, including government finance and infrastructure. In short, hosting refugees may put pressure on the national economy of these developing countries.

In this context, it is plausible that the government becomes more accepting of refugees if the economic incentive is provided to the host country. International organizations, for instance, can provide humanitarian assistance that reduces the host country's burden. More importantly, the international aid offered to the refugees also finds its way to support the locals, the so-called "spillover effect" (Jacobsen 2002; Taylor et al. 2016; Ongpin 2008). The construction of infrastructures, such as roads and bridges, is also provided to the local communities and left behind even after the refugee situation is settled (Jacobsen 2002, 581).

The representative example of the deal that offered economic incentives to accept refugees was the EU-Turkey Deal ${ }^{8}$ in 2016 . The EU and Turkey signed the

\footnotetext{
into account, such as geographical proximity, arduous journey by boat, especially during the annual monsoon season, and tight security force of Myanmar ( $\mathrm{Ng} 2018$ ).

${ }^{8}$ Distinctively, EU-Turkey Deal was possible through their experienced negotiation between the EU and Turkey on the migration issue, especially the Readmission Treaty in 2013 (IOM 2017; Sonmez and Kirik 2017). The long interaction and negotiation might conclude the Deal to be an exceptional agreement. Yet, Bangladesh has also actively appealed for bilateral and international support to provide assistance to Rohingya refugees in Bangladesh (BAL 2020a). Evidently, Turkey's situation during the European Refugee Crisis is different from that of Bangladesh during the Rohingya Refugee
} 
Deal to jointly address the Syrian Refugee Crisis and manage irregular migration to Europe (Rygiel et al. 2016, 315-6). With the "One-to-One Initiative" of the Deal, the EU provided 6 billion euros in total for the Facility for Refugees in Turkey and liberalized Turkey citizens' visa restriction (European Commission 2016; European Council 2016). In other words, various incentives, especially the economic stimulus, have encouraged Turkey to accept Syrian refugees. Although the effect of the Deal itself is unclear and controversial, the number of crossings has drastically diminished (Heck and Hess 2017, 45; DRC 2017).

Since the 2017 military crackdown, the Bangladeshi government appealed to the international community, including the UN General Assembly and IOM (BAL 2017d; BAL 2017e; BAL 2017f). Even though Bangladesh has not explicitly asked for a deal with economic incentives, it desperately needed assistance outside the country. Hence, the presence of the deal that resembles the EU-Turkey Deal might have encouraged Bangladesh to host the refugees.

The observable implication for this explanation is that, around 2017, Bangladesh received substantial economic incentives from international organizations and/or wealthier countries. In contrast, the Malaysian government has not received a similar level of assistance. To test the observable implication, I would explore 1) the deal or agreement that provide an economic incentive to the two countries and 2) humanitarian aid exclusively for Rohingya refugees.

\section{EXPLANATION 2. GOVERNMENTS FACING LESS POLITICAL COMPETITION ARE MORE LIKELY TO ACCEPT REFUGEES}

As governments are survival-seeking, government policies toward refugees are influenced by domestic politics. The survival-seeking governments would hardly adopt a policy that engenders significant political opposition, including the weak ruling party and the strong opposition party. Where the government is facing significant political opposition, it is less likely to adopt risky policies that might incur an economic burden on the national economy, political and popular resistance, as doing so might threaten the regime's political survival. On the contrary, a government enjoying a strong position is less concerned about short-term economic costs; it is also likely that the government has more tools at its disposal to shape mass opinion and still maintain its popular support.

Of course, I do not mean that the incumbent with a strong position always takes a more pro-refugee stance. Instead, I suggest that all else equal, such a strong

Crisis. ASEAN did not come forward to resolve the crisis; thus, Bangladesh had to rely on bilateral support to handle the crisis, including Indonesia, Palestine, and countries in Europe (BAL 2017a; BAL 2017b; BAL 2017c). 
political position allows the incumbent to frame the situation and its response to its political advantage. According to Slothuus and Vreese (2010), political predisposition increases the likelihood of following the frames sponsored by political parties that people support. In other words, the narratives set by the political party with people's strong support are more likely to gain attention and be favorably assessed by its supporters. However, if media narratives are set by the political party with soft backing, such narratives are more likely to be ignored or even be refuted (Slothuus and Vreese 2010, 632).

Existing studies identify a diverse range of narratives on refugee issues. It is suggested that the narrative of suffering based on a sympathetic tone tends to be prevalent at the beginning of the refugee crisis (Ehmer and Kothari 2020; Georgiou and Zaborowski 2017; Yesmin 2016). The narrative is about how incoming refugees were exposed to devastating situations in their home country and on their way to arrive at the host country. Another standard narrative regarding the host government is that the host states and their officials are the "heroes" to express concern and care for the refugees (Brooten 2015; Ehmer and Kothari 2020; Lewis 2019). However, as the refugee situation gets prolonged, the narrative radically incorporates suspicion and hate speech (Ehmer and Kothari 2020; Georgiou and Zaborowski 2017). The longer the protracted refugee situation continues, the more hostility towards refugees rises.

Domestic politics has a way of intervening in such diverse narratives (UNHCR 2020d). The media, governmental and opposition actors, and especially political parties interact via domestic political institutions and shape the dominant narrative. The observable implication for this explanation is that in Bangladesh, the government firmly controls the narrative of the crisis, and there is a weak presence of the suspicion and hostility narrative in the media. In contrast, the Malaysian government is limited to govern the narrative due to the fierce political competition; in media, there are multiple sources and types of narratives in Malaysia.

\section{OTHER EXPLANATIONS}

Of course, there are other factors that might explain the regional response to the Rohingya Refugee Crisis. From the refugees' point of view, Bangladesh might be preferable to other neighboring countries, including Malaysia. In other words, refugees might have selected their destination countries according to their personal preferences.

Many studies were done on whether the refugees and asylum seekers are active when selecting a destination country based on the concept of "agency" in migration theory (McAuliffe and Jayasuriya 2016). However, in most cases, 
refugees could hardly make an active choice of the destination countries. It is often argued that the choice of destination is accidental and incidental for the refugees, who fled to primarily seek refuge in countries nearby to get away from the immediate threat (Böcker and Havinga 1998; Day and White 2002; Gilbert and Koser 2006). In other words, the refugees are the ones with no choice but to flee to neighboring countries to be safe from the fear of persecution. ${ }^{9}$

Notwithstanding, most scholars agree that the refugees' final destination of the 'onward movement' tends to be chosen by the refugees themselves (Bijleveld and Taselaar 2000; Böcker and Havinga 1997; Gilbert and Koser 2006). Some Rohingya refugees voluntarily fled to Malaysia and other countries from Bangladesh due to problems of the refugee camps (Institute Statelessness and Inclusion 2020; Wahab and Khairi 2019). Unfortunately, these 'boat people' were still rejected by Malaysia and other countries. The 'boat crisis' again highlighted the refugees' choice of destination could hardly be made without the host countries' support and willingness to accept them.

Another alternative explanation suggested by an existing study is the affinity between Bangladesh and Rohingya people through cultural and religious identity, shared history, and especially traumatic past of Bangladesh (Sajjad 2020). In 1971, Bangladesh's people had to seek refuge in India during the war of independence from Pakistan, which might be seen as similar to the situation Rohingya faces now (Sajjad 2020; Yhome 2018). These factors might have increased the sense of affinity towards Rohingya. However, this affinity explanation is at odds with the restrictive stance of the Bangladesh government prior to 2017, including the refoulement of Rohingyas in 1992-1993.

In addition, Malaysia's membership of ASEAN might have blocked Malaysia from actively accepting Rohingya refugees as doing so could violate the principle of non-interference, the core principle of ASEAN (Acharya 2001; Narine 2008). Allegedly, Bangladesh has greater leeway to host refugees who fled from Myanmar. In the Rohingya Refugee Crisis, however, Malaysia was one of the most vocal members in raising awareness, criticizing ASEAN headquarter for not engaging in the crisis (Waikar et al. 2019, Hutt 2016). Also, in the past, Malaysia "often violated 'good neighbor' rule [of ASEAN] by taking in people fleeing their neighboring states" during the Indochinese Refugee Crisis (Davies 2008, 226). Furthermore, Malaysia is a member state of both ASEAN and OIC that showed

\footnotetext{
${ }^{9}$ Instead, it is the proactive migrants, "who have greater freedom in deciding whether to move as well as in their choice of destination and the opportunity of returning, " that can actively choose their preferred destination (Richmond 1993; McAuliffe and Jayasuriya 2016). That is why the discussion of destination is often limited to these proactive migrants, not the refugees (Richmond 1993; McAuliffe and Jayasuriya 2016).
} 
two conflicting paths towards Rohingya Refugee Crisis. When ASEAN ${ }^{10}$ was being criticized for its inaction (Human Rights Watch 2020a; MSF 2019; Piromya 2020), OIC and its member states ${ }^{11}$ actively supported Rohingya refugees (Jati 2017). In other words, it seems unlikely that Malaysia's strong commitment to the norm of non-interference drove its actions during the Rohingya Refugee Crisis.

\section{RESEARCH METHOD}

I would test the two explanations developed in the previous section through the "structured, focused comparison" method (George 1979; George and Bennett 2005). According to George and Bennett $(2005,67)$, the method is "structured" as "the general questions that reflect the research objective would be asked of each case" to achieve "systematic comparison." The method is "focused" as the research "deals only with certain aspects of historical cases examined" in light of a well-defined set of theoretical questions or propositions (George and Bennett 2005, 67).

In the previous section, I derived two propositions on the outcome of my interest, acceptance of refugees, in which two independent variables are identified: economic incentives and incumbent's political leeway. My structured, focused comparison thus centers on how these theoretically motivated variables play out in the two cases. The first variable, economic incentives, would be operationalized in both countries in terms of: 1) any deal or agreement that provided an economic stimulus and 2) humanitarian aid exclusively for Rohingya refugees. The second variable, incumbent's political leeway, are examined in both countries in terms of 1) political competition and 2) media narrative regarding Rohingya refugees.

With the research method being explained, I provide my findings in the following section to understand the divergent responses to the Rohingya Refugee Crisis.

\footnotetext{
${ }^{10}$ Still, ASEAN held several meetings to implicitly address the related issue, including the Special Meeting on Irregular Migration in the Indian Ocean and ASEAN Intergovernmental Commission on Human Rights (Jati 2017, 21-5). However, ASEAN could not specifically address the crisis and explicitly challenge the internal affairs of Myanmar due to the principle of non-interference (Jati 2017, 22).

${ }^{11}$ OIC's efforts to support Rohingya Muslims include providing humanitarian assistance, working with the UN, sending a fact-finding mission to research the root cause of the Crisis (Jati 2017, 25-8).
} 
Table 2. Outline of the research method

\begin{tabular}{|c|c|c|c|}
\hline $\begin{array}{l}\text { Theoretically Motivated } \\
\text { Critical Variables }\end{array}$ & Operationalization & Cases & Expectations \\
\hline \multirow{4}{*}{ 1. Economic incentives } & \multirow{2}{*}{$\begin{array}{l}\text { 1) deal or agreement that provided } \\
\text { an economic incentive }\end{array}$} & Bangladesh & 0 \\
\hline & & Malaysia & $\mathrm{X}$ \\
\hline & \multirow{2}{*}{$\begin{array}{l}\text { 2) humanitarian aid exclusively for } \\
\text { Rohingya refugees (RR) }\end{array}$} & Bangladesh & 0 \\
\hline & & Malaysia & $x$ \\
\hline \multirow{4}{*}{$\begin{array}{l}\text { 2. Incumbent's political } \\
\text { leeway }\end{array}$} & \multirow{2}{*}{ 1) political competition } & Bangladesh & $\begin{array}{l}\text { a strong ruling party and } \\
\text { a weak opposition party } \\
\rightarrow \text { less competition }\end{array}$ \\
\hline & & Malaysia & $\begin{array}{l}\text { a weak ruling party and } \\
\text { a strong opposition party } \\
\rightarrow \text { strong competition }\end{array}$ \\
\hline & \multirow{2}{*}{ 2) media narrative regarding $R R$} & Bangladesh & $\begin{array}{l}\text { weak presence of the suspicion } \\
\text { and hostility narrative of RR }\end{array}$ \\
\hline & & Malaysia & $\begin{array}{l}\text { presence of the suspicion } \\
\text { and hostility narrative of RR }\end{array}$ \\
\hline
\end{tabular}

Source: Author

\section{FINDING}

\section{ECONOMIC INCENTIVES}

\section{BANGLADESH}

Bangladesh's acceptance of Rohingya refugees is unlikely to have been driven by economic benefits. First of all, a deal or agreement similar to the EU-Turkey Deal was absent. Although Bangladesh is a member of ASEAN Regional Forum (ARF), ASEAN did not adopt any agreement to encourage the neighboring countries to accept the refugees.

Then, the next question is whether the presence of these refugees has brought economic gain to Bangladesh. Since Bangladesh opened its border to Rohingya refugees in 2017, diverse forms of humanitarian assistance, including funding and in-kind contribution, have been provided to Bangladesh. With the lack of the Deal that encourages the country to accept refugees, humanitarian assistance might be the key to explaining the state's action not to repatriate the refugees involuntarily.

The significant international funding exclusively for coordinating the Rohingya Crisis is the Joint Response Plan (JRP), under the leadership of the government of Bangladesh and the humanitarian community led by Inter-Sector 
Coordination Group (ISCG) in Cox's Bazar and Strategic Executive Group (SEG) in Dhaka (ISCG 2019a, 4). The JRP's target incorporates both the Rohingya refugee population and the affected host communities (ISCG 2017; ISCG 2019a; ISCG 2019b). For these two main targets, the JRP lays out the strategic plan to provide "life-saving basic assistance" by estimating the required amount of funding and monitoring the overall coordination (ISCG 2017, 5). By analyzing the critical sectors of assistance and calculating the necessary amount of funding, the JRP also calls for more active cooperation worldwide. The international humanitarian financing through JRP comes from the government, IGOs, NGOs, pooled funds, private organizations/foundations, and UN agencies (OCHA 2020).

Table 3. Funding through Joint Response Plan (JRP)

\begin{tabular}{l|c|c|c}
\hline & $\begin{array}{c}\text { Total Requirements of } \\
\text { Plan (US \$) }\end{array}$ & $\begin{array}{c}\text { Funded through This } \\
\text { Plan (US \$) }\end{array}$ & $\begin{array}{c}\text { Unmet Requirement } \\
\text { (US \$) }\end{array}$ \\
\hline $\begin{array}{l}2017 \text { JRP } \\
\text { Sept 2017- Feb 2018 }\end{array}$ & $\$ 434.1 \mathrm{~m}$ & $\$ 316.5 \mathrm{~m} \mathrm{(73 \% )}$ & $\$ 117.5 \mathrm{~m} \mathrm{(27 \% )}$ \\
\hline $\begin{array}{l}\text { 2018 JRP } \\
\text { March 2018-Dec 2018 }\end{array}$ & $\$ 951 \mathrm{~m}$ & $\$ 684 \mathrm{~m} \mathrm{(72 \% )}$ & $\$ 266 \mathrm{~m} \mathrm{(28 \% )}$ \\
\hline $\begin{array}{l}2019 \mathrm{JRP} \\
\text { Jan 2019-Dec 2019 }\end{array}$ & $\$ 920.1 \mathrm{~m}$ & $\$ 692.5 \mathrm{~m} \mathrm{(75 \% )}$ & $\$ 228 \mathrm{~m} \mathrm{(25 \% )}$ \\
\hline
\end{tabular}

Source: OCHA (2020)

The table shows that the fund has met only about 70 percent of the required amount, which puts massive pressure on the host government and humanitarian community to cover up the unmet requirement. Of course, there would be other forms of international financing for these refugee populations. For example, in 2018, both the World Bank (WB) and the Asian Development Bank (ADB) have proposed grant financing that includes a grant of USD 480 million from the WB and a grant of USD 200 million from the ADB (ISCG 2019b, 13). However, even if sufficient aid is provided, the humanitarian aid could only be used to its distinct targets: Rohingya refugees and affected host communities (ISCG 2017; ISCG 2019a; ISCG 2019b). In other words, the aid could not be used for the host country in general. The assistance is carefully monitored and assessed through the JRP to ensure that it is not used for other purposes. Moreover, the aid is used for the sectors that the JRP lays out as "needs," including food security, nutrition, shelter, WASH (Water, Sanitation and Hygiene), health, etc. (ISCG 2017; ISCG 2019a; ISCG 2019b). Hence, international humanitarian funding is limited to bring economic benefit to Bangladesh.

In addition to the international humanitarian assistance, neighboring countries of Bangladesh have provided funding and in-kind contributions to 
support Bangladesh. Malaysia is one of the countries that delivered "significant financial and humanitarian aid" to refugee populations in Bangladesh (Sukhani 2020). Specifically, the Malaysian government has built a hospital in Cox's Bazar at the cost of 3.5 million Malaysian ringgits (Sukhani 2020). Indonesia and other neighboring countries such as India and Thailand have sent in-kind contributions to Cox's Bazar the relief packet, including "rice, ready meals, family kits, tents, and blankets" (AP News 2017; Rohmah 2017). Some scholars note that Malaysia's assistance to Bangladesh is motivated in part to make the refugee population stay in Bangladesh (Yhome 2018, 4).

In essence, neither international organizations nor wealthier neighboring countries have provided economic incentives to Bangladesh in return for accepting refugees. Although the country-based pooled fund of JRP is provided, humanitarian aid is limited to eliminating the economic burden on the Bangladeshi government.

\section{MALAYSIA}

Like Bangladesh, the economic incentive to motivate countries to accept Rohingya refugees was not provided to Malaysia. Different from Bangladesh, Malaysia being a member state of ASEAN and the chairman in 2015 did not make any difference to trigger active action from ASEAN. Instead, being vocal on the Rohingya Refugee Crisis was all it took for the ASEAN to engage in the crisis during the Malaysian chairmanship (Waikar et al. 2019, 16).

Moreover, as Malaysia has not actively opened its border to refugees, humanitarian aid exclusively for Rohingya refugees in Malaysia was not formed. In other words, there was no humanitarian aid that resembles the JRP of Bangladesh. The lack of humanitarian assistance to Rohingya refugees is self-explanatory as the Rohingya refugee population and refugee camps are not as big as those in Bangladesh.

However, since June 2020, the number of Rohingya refugees entering Malaysia rapidly increased once again as the Rohingya have also started to reach Malaysia by boat (IOM 2020). Until 7 September 2020, 395 Rohingya refugees disembarked in the region (IOM 2020). Therefore, IOM, UNHCR, and the United Nations Office on Drugs and Crime (UNODC) have appealed to the international community for humanitarian support to Malaysia (UNHCR 2020e; IOM 2020). Just like the JRP, IOM estimated the funding requirements with four main sectors: health \& nutrition, protection, accommodation, and cash-based intervention (IOM 2020). The appeals from the international agencies are ongoing to meet the funding requirements.

In this way, it is clear how humanitarian aid is provided when countries accept 
refugees to some extent. While international organizations are trying to attract humanitarian assistance for 'boat people,' they consistently provided humanitarian aid to Malaysia for the refugees in general. Although it has closed its border towards Rohingya refugees, Malaysia is the largest host country for refugees within the region, besides Bangladesh (European Commission 2019). That is why Malaysia was provided with aid for refugee protection in general.

These findings together suggest that Explanation 1 should be rejected. The economic stimulus that resembles the EU-Turkey Deal was not provided to Bangladesh nor Malaysia. Although Bangladesh is provided with aid specifically for Rohingya refugees, economic pressure cannot be fully lifted. Contrary to Bangladesh, Malaysia receives less funding due to its small number of Rohingya refugees. Hence, the external economic inducement is not the factor that motivated Bangladesh to accept refugees.

\section{INCUMBENT'S POLITICAL LEEWAY}

\section{BANGLADESH}

\section{Domestic Politics}

Bangladesh's domestic politics is often described as "the rivalry between the Awami League (AL) led by Sheikh Hasina and Bangladesh Nationalist Party (BNP) led by Khaleda Zia" (Idris 2017, 4). Since 2009, the AL remains in power and authoritarianism has gradually deepened with institutionalized authoritarian policies (Mostofa and Subedi 2020, 14-9). Since then, Bangladesh's domestic politics concentrated the power on AL's ruling party by controlling its opposition party, judiciary system, and local government.

The deepened authoritarianism within Bangladesh is primarily due to the extreme marginalization of political opposition that eliminates opposition and dissenting voices, an "oppositional void" (Mostofa and Subedi 2020, 14). The most common way for the AL to 'silence its opposition and dissenting voices' is to arrest and prosecute the opposition. More than 30,000 criminal cases were issued against the Bangladesh National Party (BNP) leaders and supporters, and 8,000 were arrested before the election (Siddiqui et al. 2018; Antara 2018). The BNP argued that the allegations of 30,000 cases were "false and fabricated cases," as the allegations were not specific and ambiguous (Human Rights Watch 2018b, 4). Moreover, the allegations clarified that all the accused were members of the BNP. These allegations were politically motivated as some charges were "ghost cases" as the accused were "either dead, abroad, or hospitalized when the alleged offense 
took place" (Human Rights Watch 2018b, 4; Mostofa and Subedi 2020, 15). These attacks against the BNP are how the marginalized opposition party became eliminated by the ruling party, AL. The lack of a strong opposition party implies that check and balance within the political parties would be less likely to occur, which automatically leads to a de facto one-party system (Mostofa and Subedi 2020, 16).

The weak 'check and balance' within domestic politics continues through the institutionalization of authoritarian policies: the Digital Security Act 2018 and the 16th constitutional amendment. Firstly, the Digital Security Act of 2018 is the domestic legal framework that restricts free speech. The Act is far more dangerous than the previous ICT law that provides much more unlimited power to the security forces that ultimately restricts freedom of expression of journalists, public intellectuals, and civil society activists (Hasan 2018). For about three months after enacting the Act, 63 people have been arrested for their activities against the prime minister, her father, and the government on social media (Rashid 2019). The Act is a useful tool for the AL and prime minister to rule out dissenting voices, providing more tools at their disposal to shape the narratives for its own good.

Secondly, the 16th amendment of the constitution has further distorted the separation of power that empowered the AL through its control over the judiciary and local government election system. Although the Constitution of Bangladesh stipulates the independence of the judiciary, the judiciary's autonomy has been continuously minimized through the amendment of the constitution by the parliament. Through the 16th amendment, the parliament positioned itself superior to the judiciary (Mostofa and Subedi 2020, 17). The president's permission is required for the Supreme Judicial Council to initiate any legal action, and the president should act in accordance with the prime minister, according to Article 48(3). Furthermore, the Ministry of Law has the authority to "post, promote, and transfer the judges" (Sobhan 2017). In this way, the judiciary's independence is repeatedly attacked through the control of the parliament and the prime minister.

Additionally, the 16th amendment critically affected the local government election system that the new election policy only allows political parties to nominate candidates. The nomination system is illustrated as "institutionalized patronage politics," in which a candidate's loyalty towards the party is prioritized over his or her political performance (Mostofa and Subedi 2020, 18). The shift of the local government election system fosters an "elitist game" rather than reinforcing a bottom-up representation (Mostofa and Subedi 2020, 18). In this way, Bangladesh's domestic politics is explained through the oppositional void and distorted separation of power through arresting and persecuting the 
opposition, restricting free speech, low autonomy of the judiciary, and patronage of local government politics.

\section{Narrative}

Bangladesh's domestic political environment enables Rohingya-related narratives to be unilateral, reflecting how the government has framed the Rohingya refugee crisis for its political gain. Like Malaysia, these narratives were analyzed by searching the term "Rohingya" from articles in the governmentcontrolled media platform Bangladesh Sangbad Sangstha (BSS), National News Agency of Bangladesh, issued from April 612, 2017, to December 31, 2017. Being officially owned by the government, the Chief Editor of BSS is the former Press Secretary of prime minister Hasina, Abul Kalam Azad, that reasonably represents the media narrative formed by the government (BSS 2021b). Out of 93 articles, 61 articles were analyzed by excluding repetitive articles and international news and classified by the four categories set by Ehmer and Kothari (2020).

Table 4. Narrative analysis (number of articles in each category)

\begin{tabular}{c|l|c|c|c}
\hline 4 Categories & \multicolumn{1}{|c|}{ Explanation } & $\begin{array}{c}\text { April 6, 2017 } \\
\text { - August 24, 2017 }\end{array}$ & $\begin{array}{c}\text { August 25, 2017 } \\
\text { - December 31, 2017 }\end{array}$ & Total \\
\hline "Stereotype" & $\begin{array}{l}\text { Rohingya refugees labelled as } \\
\text { illegal immigrants or criminals }\end{array}$ & 1 & 0 & 1 \\
\hline $\begin{array}{c}\text { "Local/humanitarian } \\
\text { narrative" }\end{array}$ & $\begin{array}{l}\text { Government and civil society's } \\
\text { engagement to address Rohingya } \\
\text { Refugee Crisis }\end{array}$ & 1 & 30 & 31 \\
\hline $\begin{array}{c}\text { "Sovereignty/border } \\
\text { narrative" }\end{array}$ & $\begin{array}{l}\text { Government's border control and } \\
\text { security threat that the refugees } \\
\text { pose }\end{array}$ & 1 & 1 & 2 \\
\hline $\begin{array}{c}\text { "International / } \\
\text { regional narrative" }\end{array}$ & $\begin{array}{l}\text { Implication of need for addressing } \\
\text { Rohingya Refugee Crisis at } \\
\text { regional and international level }\end{array}$ & 2 & 28 & 30 \\
\hline
\end{tabular}

Source: BSS (2021a), Author

Similar to Malaysia, the narratives on government's effort to support Rohingya refugees and the need for regional and international assistance were mainly addressed. Interestingly, among the articles on "local/humanitarian narrative" and "international/regional narrative," prime minister Hasina was explicitly praised by describing her as "Mother of Humanity" and "New Star of the East"

\footnotetext{
12 The archive of BSS dates back to March 20, 2017, and the article that addresses Rohingya start from April 6, 2017 (BSS 2021a).
} 
(BSS 2017a), which is quite common narratives used in a refugee situation (Lewis 2019; Ehmer and Kothari 2020; Brooten 2015; BAL 2020b). Many articles specifically highlighted the prime minister's endeavors towards Rohingya refugees while emphasizing that the international community well recognizes her effort.

Few articles appealed to Bangladesh's people as in shared religious belief with Rohingya but instead appealed to the refugees' situation (BSS 2017c). Regarding the Rohingya refugees, the refugees' devastating conditions were underscored while demonizing Aung San Suu Kyi and Myanmar. In line with the criticism towards Myanmar, the opposition party BNP's inaction was also addressed in a few articles by articulating the opposition leader "did nothing for the Rohingya" (BSS 2017b). Also, the government's control over the crisis management shows that "everything is under control by the government" (Lewis 2019, 1896). Through shaping and dominating these narratives, the government could promote its legitimacy as the government was accused of its authoritarian governance.

Owing to the government and the AL strategies on dominating these narratives, its management of the Rohingya Refugee Crisis and its commitment to boost the national economy have contributed to the complete win in the 2018 General Election (DW 2018). In the election, the ruling coalition secured $96 \%$ of public support, 288 seats out of 298 seats (258 AL seats and 22 Jatiya Party seats), whereas BNP and its allies only won 7 seats (Safi et al. 2018). Compared to the previous general election in 2014, the AL gained 24 additional seats, 234 seats back then (International Crisis Group 2015, 7). According to the national survey by the International Republican Institute (IRI) in May 2018, 66\% supported prime minister Hasina, along with 64\% supported the government (IRI 2018, 7). Indeed, the success of the 2018 election and high support rate are caused by various factors other than the government-formulated narratives. Still, the government's management of the Rohingya Crisis has contributed to the rise of support to the government (DW 2018).

However, what is missing in these narratives is the most common narrative of refugees that the incoming refugees are "violent, criminals, and illegal outsiders" (Ehmer and Kothari 2020; Brooten et al. 2015; Kaur 2007; Siddiquee 2019). The most widespread refugee narrative being excluded is atypical for a country with a relatively long history of irregular but consistent inflow. The existence of narratives that only supports the government stance again implies that political struggle within domestic politics is weak.

Hence, the Bangladeshi government's firm position over its opposition through authoritarian domestic politics enabled itself to have a greater leeway to shape the public opinion and dominate the Rohingya-related framing. Since 2017, its management and representation of Bangladesh's refugee situations have 
provided a sharp win in the 2018 general election. In other words, it was the incumbent's political leeway that ultimately led Bangladesh to host Rohingya refugees as the government transformed the crisis to political advantage through the political leeway.

\section{Malaysia}

Before directly delving into the domestic political environment, a unique national characteristic should be clarified so as to better understand the Malaysian ambivalent stance. Malaysian government's stance towards incoming Rohingya refugees is ambivalent. The government is not opened to accepting refugees while frequently expressing its concerns about the refugees' devastating situations. Intriguingly, Malaysia's multi-ethnicity leads to the ambivalence of Malaysian domestic politics and the government's ambivalent stance.

Malaysia is a multi-ethnic country that ethnicity, religion, and politics are formally intertwined (Dev 2009, 39). In other words, both ethnicity and religion are used as the means of a political bargain (Lemière 2018, 40). Most coalition parties are explicitly ethnically based or religion-based (Dev 2009, 39). For the government, government policies are designed to favor the Malay Muslim majority, take up about $67.4 \%$ of the Malaysian population (Department of Statistics Malaysia Official Portal 2015). However, since independence from the UK, Malaysia has sought to develop Malaysian identity, rather than each individual define themselves through their ethnic groups (Dev 2009, 40). Therefore, successive governments often claimed to become "protectors of Malaysian society's fragile demographic balance" and emphasized its commitment to "national unity" (Lemière 2018, 40; Dev 2009, 40).

In short, the multi-ethnicity of Malaysia formed the ambivalence of domestic politics. For the government's survival, it has to secure the majority vote from the Malay Muslim while ultimately aiming for the "One Malaysia." To increase Malay Muslims' credibility, the government has to show its humanitarian concerns to Rohingya Muslim refugees. At the same time, the government has avoided accepting refugees to achieve a united nation of Malaysia. The government's stance is further fixated through the ruling government's efforts for its survival, which would be further elaborated.

\section{Domestic Politics}

The ruling BN coalition led by Najib Razak was already weak because the coalition was elected with the smallest majority (Lemière 2018, 40). It was especially unusual for Malaysia because the BN coalition has been the ruling party since its independence, which used to imply long lasting popular support 
to the government. To make matters worse, the prime minister was involved in two political scandals, which further aggravated the BN coalition situation. In 2015 , he was directly involved in the "greatest global financial scandal," which is the allegation of mismanagement of the state investment fund of 1Malaysia Development Berhad (Welsh 2020, 45). In 2017, the prime minister was again involved in another scandal regarding the arms deal between the Malaysian government and a French company unfit for Malaysian defense (Lemière 2018, 41). With these scandals, an emergence of a strong opposition leader Mohammed Mahathir has further shaken Najib's position in domestic politics.

In 2016, the Malaysian political scene dramatically changed due to Mahathir's joining of the opposition coalition while resigning from the United Malays National Organization (UMNO) (Welsh 2020, 45; Lemière 2018, 43). Mahathir is a former prime minister as a UMNO leader during 1981 and 2003, often described as a former dictator (Lemière 2018, 43). However, he resigned from the UMNO and joined the opposition coalition that he once had repressed (Lemière 2018, 43). Since then, Mahathir has attempted to erase his authoritarian past and to earn Malaysian's credibility. He actively participated in the "Bersih rally," a series of peaceful protests demanding free and fair elections, which was a chance for him to publicly condemn the corrupt government of Najib (Holmes 2015; Paddock 2016). Mahathir further attempted to reposition himself as "a champion of democracy" by admitting his past authoritarian governance (Lemière 2018, 43). Mahathir's path was successful, which his coalition members ultimately agreed on forming a new coalition of Pakatan Harapan (PH) (Welsh 2020, 45-6; Lemière 2018 , 43). The strong opposition leader made the ruling government of Najib much more vulnerable.

Undoubtedly, the weakened BN coalition was keen to obtain Malay Muslim's votes and distract attention from the corruption allegation (Hutt 2016). For the ruling coalition's survival, the government had to strategically use an ethnic and religious card, the Rohingya Refugee Crisis. The Malaysian government showed a dramatic shift that Malaysia became vocal on the refugee issues by its cha irmanship of ASEAN.

Through the Malaysian 2015 chairmanship of ASEAN, prime minister Razak promoted awareness of the Rohingya Crisis and criticized Myanmar's failure (Waikar et al. 2019, 16). In 2016, prime minister Razak organized a public rally regarding the crisis in response to the Myanmar government's criticism that Malaysia should stay out of Myanmar's internal affairs (Hutt 2016). At the rally, the prime minister described Rohingya persecution in Myanmar as genocide and explicitly criticized Aung San Suu Kyis failure (Hutt 2016; Waikar et al. 2019). After the 2017 military crackdown, the prime minister Razak met President Donald 
Trump. Through the meeting, prime minister was again able to express his ability to commit to resolving the Rohingya Refugee Crisis as a middle-power role (Lemière 2018, 44).

To further safeguard the majority support, the government had to keep the Rohingya refugees from entering the border. Besides, it is the illegal immigrants, asylum seekers, and refugees that exacerbate the already fragile ethnic balance (Dev 2009, 40). As the government does not distinguish refugees from illegal immigrants, these groups are all "foreigners" that are unwanted from the Malaysian society (Dev 2009, 40). Interestingly, the "othering" of foreigners promoted ethnic balance and nation-building of Malaysia. Due to this very context, the Malaysian government was keen to avoid accepting refugees.

In short, the weak ruling coalition further galvanized through political scandals, and the strong opposition coalition has caused relatively robust domestic opposition. The government's vulnerable position with Malaysia's unique trait being multi-ethnic has restricted the government to actively formulate the pro-refugee narratives.

\section{Narrative}

The domestic political environment of Malaysia allows Rohingya-related narratives to be diverse and broad. Ehmer and Kothari (2020) analyzed the refugee-related narratives in search of the term "Rohingya" from articles in "The Star" written from January 1, 2012, to December 31, 2016. Searched articles in "The Star," one of the major English newspapers in Malaysia to be deeply associated with the government, were analyzed by the four categories explained in Table 5. Borrowing Ehmer and Kothari (2020)'s framework, I searched the term "Rohingya" in "The Star" for articles from January 1, 2017, to December 31, 2017, which resulted in 877 articles. By excluding repetitive articles, international and regional news, 135 articles were left to be analyzed according to four categories. 
Table 5. Narrative analysis (number of articles in each category)

\begin{tabular}{c|l|c|c|c}
\hline 4 Categories & \multicolumn{1}{|c|}{ Explanation } & $\begin{array}{c}\text { January 1, 2017 } \\
\text { - August, 2017 }\end{array}$ & $\begin{array}{c}\text { August 25, 2017 } \\
\text { - December 31, 2017 }\end{array}$ & Total \\
\hline "Stereotype" & $\begin{array}{l}\text { Rohingya refugees labelled as } \\
\text { illegal immigrants or criminals }\end{array}$ & 9 & 6 & 15 \\
\hline $\begin{array}{c}\text { "Local/ } \\
\text { humanitarian } \\
\text { narrative" }\end{array}$ & $\begin{array}{l}\text { Government and civil society's } \\
\text { engagement to address Rohingya } \\
\text { Refugee Crisis }\end{array}$ & 22 & 41 & 63 \\
\hline $\begin{array}{c}\text { "Sovereignty/ } \\
\text { border narrative" }\end{array}$ & $\begin{array}{l}\text { Government's border control } \\
\text { and security threat that the } \\
\text { refugees pose }\end{array}$ & 7 & 4 & 11 \\
\hline "International / & $\begin{array}{l}\text { Implication of need for addressing } \\
\text { Rohingya Refugee Crisis at } \\
\text { regional narrativenal and international level }\end{array}$ & 21 & 39 & 60 \\
\hline
\end{tabular}

Source: The Star (2021), Author

The constructed narrative towards the host country is the Malaysian government being vocal on the Rohingya Crisis, similar to that of Bangladesh that highlight the government's management of the Crisis. What is different from Bangladesh is the Malaysian government's narrative of being the "strong enforcer of immigrant law (Ehmer and Kothari 2020, 5)" to show that the government is not recklessly accepting the incoming refugees, strictly distinguishing refugees from economic immigrant ${ }^{13}$. While stressing the Malaysian government's commitment, the government's appeal for regional and international support was also emphasized. The narratives on Rohingya refugees incorporates ambivalent views. On the one hand, refugees are described as illegal immigrants or individuals possessing fake UNHCR cards, which was absent in Bangladesh's narrative after the 2017 military crackdown. On the other hand, refugees are reflected in a sympathetic tone to stress how refugees are in a dire situation.

The narrative is not only to describe the Rohingya refugees. The overall narrative of refugees in Malaysia is shaped to instigate 'animosity' of the Malaysian public and suspicion by local political parties (Dev 2009, 40). As previously mentioned, the refugees and asylum seekers in Malaysia are often viewed as illegal in their collective identity, common in the refugee-related narratives (Dev 2009, 46). The Malaysian government is reluctant to distinguish the refugees from other illegal migrants, but to regard all refugees in general

\footnotetext{
${ }^{13}$ The "non-genuine refugee argument" has become prevalent since the Indochinese Refugee Crisis as many countries in Southeast Asia argued that "the Indochinese asylums were not 'genuine' refugees" (Davies 2008, 227). Back then, the argument ends up being accepted by the vital resettlement states in the West and the UNHCR, thereby withdrawing "prima facie refugee status from the Indochinese asylum seekers" (Davies 2008, 227).
} 
being "the same" illegal immigrants and "criminals (Dev 2009, 47)." In fact, according to the survey by Ipsos in 2019, only $24 \%$ of Malaysians believe that the refugees, in general, are genuine. However, others believe that the people claiming refugees are not genuine refugees but came to Malaysia for economic reasons, hoping to take advantage of Malaysian welfare services (Ipsos 2019). Additionally, refugees' presence poses a threat to Malaysian political stability, and thus refugees do not deserve citizenship, along with the protection and rights given to the citizens (Dev 2009, 46).

These findings together provide support for Explanation 2. The observable implication was validated through the finding. The distinctively different domestic political environments of Bangladesh and Malaysia led to the divergent framings of the crisis. In the case of Bangladesh, less domestic opposition from the weak opposition party enabled the ruling government to have greater political leeway, thereby shape the narratives in favor of the government. The government's strategy of framing refugees as the sufferings and the officials being the hero has contributed to its success in the election, that is, a tangible political gain. However, the Malaysian government back then was politically weak to dominate the issue framing. Hence, what made Bangladesh more accepting of Rohingya refugees has been the political leeway the ruling government enjoyed throughout the crisis.

Table 6. Summary of Findings

\begin{tabular}{|c|c|c|c|c|}
\hline $\begin{array}{c}\text { Theoretically Motivated } \\
\text { Critical Variables }\end{array}$ & Operationalization & Cases & Expectations & Findings \\
\hline \multirow{4}{*}{ 1. Economic incentives } & \multirow{2}{*}{$\begin{array}{l}\text { 1) deal or agreement that provided } \\
\text { an economic incentive }\end{array}$} & Bangladesh & 0 & $x$ \\
\hline & & Malaysia & $x$ & $x$ \\
\hline & \multirow{2}{*}{$\begin{array}{l}\text { 2) humanitarian aid exclusively } \\
\text { for Rohingya refugees (RR) }\end{array}$} & Bangladesh & $\mathrm{O}$ & O but limited \\
\hline & & Malaysia & $x$ & $x$ \\
\hline \multirow{4}{*}{$\begin{array}{l}\text { 2. Incumbent's } \\
\text { political leeway }\end{array}$} & \multirow{2}{*}{ 1) political competition } & Bangladesh & \multicolumn{2}{|c|}{$\begin{array}{l}\text { the strong ruling party and } \\
\text { the weak opposition party } \\
\rightarrow \text { less competition }\end{array}$} \\
\hline & & Malaysia & \multicolumn{2}{|c|}{$\begin{array}{l}\text { the weak ruling party and } \\
\text { the strong opposition party } \\
\rightarrow \text { strong competition }\end{array}$} \\
\hline & \multirow{2}{*}{ 2) media narrative regarding $R R$} & Bangladesh & \multicolumn{2}{|c|}{$\begin{array}{l}\text { weak presence of the suspicion } \\
\text { and hostility narrative of RR }\end{array}$} \\
\hline & & Malaysia & \multicolumn{2}{|c|}{$\begin{array}{l}\text { presence of the suspicion and } \\
\text { hostility narrative of } R R\end{array}$} \\
\hline
\end{tabular}




\section{CONCLUSION}

Rohingya Refugee Crisis has been ongoing for decades; thus, the protracted refugee situation has incurred neighboring countries, Bangladesh and Malaysia, to close their border and to forcibly repatriate the refugees. However, the two countries' stances started to diverge since the 2017 military crackdown, a so-called "textbook example of ethnic cleansing (UN News 2017)." The Bangladeshi government has welcomed Rohingya refugees to settle down in the district of Cox's Bazar. Contrary to Bangladesh, the Malaysian border remained closed, and the government pursues a more restrictive admission policy towards the refugees. The diverging response of Bangladesh and Malaysia raised the question of 'what made Bangladesh more accepting of Rohingya refugees.'

Among the two explanations proposed, I find support for the second explanation that the governments facing less competition and thus enjoy greater political leeway are more likely to accept refugees. Ironically, it was the weak domestic political opposition that empowered Bangladesh's authoritarian government to implement more open refugee admission policies. Less political competition has enabled the government to shape the refugee-related narratives. By doing so, the government has controlled the coordination and representation of its crisis management. Through the government's strategic approach, its management of the crisis has contributed to the historic win in the 2018 General Election. On the contrary, Malaysia that faced strong domestic opposition has rarely accepted the refugees. The strong domestic political opposition, including the weak ruling party and the strong opposition party, has limited the host government to shape the refugee-related narrative.

My finding that Bangladesh's open admission of Rohingya refugees is driven by its government's ability to use the crisis to its political advantage provides somber implications. Bangladesh's open admission policy is unlikely to provide sustainable solution to the Rohingya Refugee Crisis. For political benefits, when deemed useful, the government can always promote the narrative of fear and hostility and dominate the issue framing. By doing so, it can retract the current open admission policy and go back to the restrictive stance of the 1990s with little political repercussion. Furthermore, open admission policy does not automatically lead to generous assistance and integration policies for settled refugees as the government has relocated Rohingya refugees to a "remote, flood-prone island" to "alleviate overcrowding in the Cox's Bazar refugee camps" since December 2020 (Barron 2020). While this study has limited its focus to the divergent admission policies between Bangladesh and Malaysia, future research should investigate how the two countries and the countries in the Southeast Asia vary 
in other key dimensions of refugee policies.

\section{REFERENCE}

Acharya, Amitav. 2001. Constructing a Security Community in Southeast Asia. London: Routledge.

Ahmed, Kaamil, and Rebecca Ratcliffe. 2020. "Rohingya face 'cruel' caning sentence in Malaysia as hostility to refugees grows." The Guardian (July 21). Accessed at https://www.theguardian.com/global-development/2020/ jul/21/rohingya-face-cruel-caning-sentence-in-malaysia-as-hostility-torefugees-grows (January 13, 2021).

Al Jazeera. 2020. "Unwanted: Bangladesh, Malaysia reject rescued Rohingya refugees." Al Jazeera (June 10). Accessed at https://www.aljazeera.com/ news/2020/6/10/unwanted-bangladesh-malaysia-reject-rescued-rohingy a-refugees (July 10, 2020).

Alix-Garcia, Jennifer. 2007. "The Effect of Refugee Inflows on Host Country Populations: Evidence from Tanzania." Working Paper Series: University of Montana. Accessed at http://papers.ssrn.com/sol3/papers.cfm?abstract_ $\mathrm{id}=836147$ (July 10, 2020).

Antara, Nawaz. 2018. "BNP: Ballots Boxes Getting Stuffed at Dhaka 4, 9, 14 Constituencies." Dhaka Tribune (December 30). Accessed at https://www. dhakatribune.com/bangladesh/election/2018/12/30/bnp-ballots-boxesgetting-stuffed-at-dhaka-9-14-constituencies (October 24, 2020).

AP News. 2017. "The Latest: Indonesia sends 34 tons of aid for Rohingya." AP News (September 13). Accessed at https://apnews.com/article/23feacae 668b40d892f75ab986629585 (August 30, 2020).

Bangladesh Awami League (BAL). 2017a. "HPM Sheikh Hasina seeks support for relocating Rohingyas.” BAL. Accessed at https://www.albd.org/articles/news/ 28797/HPM-Sheikh-Hasina-seeks-support-for-relocating-Rohingyas (December 2, 2020).

.2017b. "HPM Sheikh Hasina seeks Indonesia's role in solving Rohingya issue." BAL. Accessed at https://www.albd.org/articles/news/28797/HPMSheikh-Hasina-seeks-support-for-relocating-Rohingyas (December 2, 2020). 2017c. "HPM Sheikh Hasina and Palestine President discusses Rohingya issue." BAL. Accessed at https://www.albd.org/articles/news/29006/HPMSheikh-Hasina-and-Palestine-President-discusses-Rohingya-issue (December 2, 2020). 
. 2017d. "HPM Sheikh Hasina urges IOM to pressure Myanmar to take back Rohingyas." BAL. Accessed at https://www.albd.org/articles/news/29010/ HPM-Sheikh-Hasina-urges-IOM-to-pressure-Myanmar-to-take-back-Ro hingyas (December 2, 2020).

. 2017e. "Myanmar must stop violence in Rakhine immediately and forever: HPM Sheikh Hasina at UNGA." BAL. Accessed at https://www.albd. org/articles/news/31214/Myanmar-must-stop-violence-in-Rakhine-imm ediately-and-forever:-HPM-Sheikh-Hasina-at-UNGA (December 2, 2020). . 2017f. "Finance Minister seeks UN's support to create 'Safe Zone' to solve Rohingya crisis.” BAL. Accessed at https://www.albd.org/articles/news/ 31211/Finance-Minister-seeks-UN's-support-to-create-'Safe-Zone'-to-sol ve-Rohingya-crisis (December 2, 2020).

2020a. "BAL." Accessed at https://www.albd.org/ (October 26, 2020). 2020b. "Sheikh Hasina: Daughter of Democracy and Herald of Change. Special Articles." BAL. Accessed at https://www.albd.org/articles/news/ 31112/Sheikh-Hasina:-Daughter-of-Democracy-and-Herald-of-Change (September 5, 2020).

Bangladesh Sangbad Sangstha (BSS). 2017a. "Cabinet approves Health Development Surcharge Management Policy." BSS (October 17). Accessed at www. bssnews.net/?p=5651 (January 13, 2021).

. 2017b. "People will reply to falsehood of Khaleda in next polls: Nasim." BSS (November 11). Accessed at www.bssnews.net/?p=7165 (January 13, 2021).

. 2017c. "Durga Puja begins tomorrow amid festivity." BSS (September 25). Accessed at www.bssnews.net/?p=5067 (January 13, 2021). 2021a. Accessed at http://www.bssnews.net (January 13, 2021).

. 2021b. "Managing Director and Chief Editor's Profile." BSS. Accessed at http://www.bssnews.net/?page_id=556 (January 13, 2021).

Barron, Laignee. 2020. "Bangladesh Begins to Relocate Rohingya Refugees to Flood-Prone Island." Time (December 3). Accessed at https://time.com/ 5917334/bangladesh-rohingya-relocation-island/ (March 8, 2021).

BBC. 2021. "Malaysia deports Myanmar nationals despite court order." $B B C$ News (February 24). Accessed at https://www.kjis.org/authors/sub01. html (March 5, 2021).

Bijleveld, Catrien, and A.P. Taselaar. 2000. "Motives for Asylum Seekers to Come to the Netherlands: Summary of an Expert Meeting." the Hague: Netherlands Ministry of Justice. Accessed at https://www.ojp.gov/ncjrs/virtual-library/ abstracts/motives-asylum-seekers-come-netherlands-summary-expertmeeting (December 3, 2020). 
Böcker, Anita, and Tetty Havinga. 1998. "Asylum Migration to the European Union: Patterns of Origin and Destination.” Luxemburg: European Communities. Accessed at https://ssrn.com/abstract=2633536(December 3, 2020).

Brooten, Lisa. 2015. "Blind spots in human rights coverage: Framing violence against the Rohingya in Myanmar/Burma." Popular Communication, 13(2), 132-144.

Brooten, Lisa, Syed Irfan Ashraf, and Ngozi Akinro. A. 2015. "Traumatized victims and mutilated bodies: Human rights and the 'politics of immediation' in the Rohingya Crisis of Myanmar." International Communication Gazette, 77(8), 717-734.

Central Intelligence Agency (CIA). 2020a. "The World Factbook Archive. Southeast Asia: Bangladesh.” CIA. Accessed at https://www.cia.gov/library/publications/ the-world-factbook/geos/bg.html (November 9, 2020).

2020b. "The World Factbook Archive. Southeast Asia: Malaysia." CIA. Accessed at https://www.cia.gov/library/publications/the-world-factbook/ geos/my.html (November 9, 2020).

Danish Refugee Council (DRC). 2017. "DRC Turkey: Mixed Migration Monthly Update." DRC. Accessed at https://reliefweb.int/report/turkey/drc-turkeymixed-migration-monthly-update-april-2017 (August 15, 2020).

Davies, Sara E. 2008. Legitimizing Rejection: International Refugee Law in Southeast Asia. Leiden, Netherlands: Brill.

Day, Kate, and Paul White. 2002. "Choice or circumstance: The UK as the location of asylum applications by Bosnian and Somali refugees." Geo Journal, $56(1), 15-26$.

Department of Statistics Malaysia Official Portal. 2015. "Population Distribution and Basic Demographic Characteristic Report.” The Source of Malaysia's Statistics. Accessed at https://www.dosm.gov.my/v1/index.php?r=column/ ctheme\&menu_id=L0pheU43NWJwRWVSZklWdzQ4TlhUUT09\&bul_id= MDMxdHZjWTk1SjFzTzNkRXYzcVZjdz09 (November 31, 2020).

Deutsche Welle (DW). 2018. Bangladesh election: Prime Minister Sheikh Hasina wins by landslide. $D W$ (December 31). Accessed at https://www.dw.com/ en/bangladesh-election-prime-minister-sheikh-hasina-wins-by-landsli de/a-46902833 (January 18, 2021).

Dev, Sanjugta. 2009. "Accounting for state approaches to asylum seekers in Australia and Malaysia: The significance of national identity and exclusive citizenship in the struggle against irregular mobility." Identities: Global Studies in Culture and Power, 16(1), 33-60.

Ehmer, Emily, and Ammina Kothari. 2020. "Malaysia and the Rohingya: Media, 
Migration, and Politics." Journal of Immigrant \& Refugee Studies. 1-15. European Commission. 2016. "Relocation and resettlement: EU member states urgently need to deliver European Commission." Press release of European Commission. Accessed at http://europa.eu/rapid/press-release_IP-16-829_ en.htm (August 15, 2020).

2019. "European Civil Protection and Humanitarian Aid Operations: Thailand, Malaysia, and Indonesia." European Commission. Accessed at https://ec.europa.eu/echo/where/asia-and-pacific/thailand_en (November 6, 2020).

European Council. 2016. "EU-Turkey statement, 18 March 2016." European Council. Accessed at https://www.consilium.europa.eu/en/press/pressreleases/2016/03/18/eu-turkey-statement/ (August 20, 2020).

Fuller, Thomas, and Joe Cochrane. 2015. "Rohingya Migrants From Myanmar, Shunned by Malaysia, Are Spotted Adrift in Andaman Sea." The New York Times (May 14). Accessed at https://www.nytimes.com/2015/05/15/world/ asia/burmese-rohingya-bangladeshi-migrants-andaman-sea.html (July 10, 2020).

George, Alexander L. 1979. "Case Studies and Theory Development: The Method of Structured, Focused Comparison." In Paul Gordon Lauren ed., Diplomacy: New Approaches in History, Theory, and Policy, New York: Free Press, 43-68.

George, Alexander L, and Andrew Bennett. 2005. Case Studies and Theory Development in the Social Sciences. Cambridge, Massachusetts: MIT Press.

Georgiou, Myria, and Rafal Zaborowski. 2017. "Council of Europe report: Media coverage of the "refugee crisis": A cross-European perspective." Strasbourg: Council of Europe. Accessed at https://edoc.coe.int/en/refugees/7367media-coverage-of-the-refugee-crisis-a-cross-european-perspective.ht $\mathrm{ml}$ (September 6, 2020).

Gilbert, Alan, and Khalid Koser. 2006. "Coming to the UK: What do AsylumSeekers Know About the UK before Arrival?" Journal of ethnic and migration studies, 32(7), 1209-1225.

Hasan, Rashidul. 2018. “Digital Security Bill Passed.” The Daily Star(September 20). Accessed at https://www.thedailystar.net/politics/bangladesh-jatiyasangsad-passes-digital-security-bill-2018-amid-concerns-journalists-16 36114 (April 20, 2020).

Heck, Gerda and Sabine Hess. 2017. "Tracing the Effects of the EU-Turkey Deal The Momentum of the Multi-layered Turkish Border Regime." Movements 3(2), 35-56. 
Holmes, Oliver. 2015. "Malaysian police to question former PM Mahathir over anti-government rally." The Guardian (September 2). Accessed at https:// www.theguardian.com/world/2015/sep/02/malaysian-police-questionmahathir-anti-government-rally-bersih (November 10, 2020).

Human Rights Watch. 2000. "Malaysia/Burma: Living in Limbo: Burmese Rohingya in Malaysia." Human Rights Watch. Accessed at http://www.hrw.org/ legacy/reports/2000/malaysia/index.htm (May 20, 2020).

. 2018a. "Bangladesh Is Not My Country." Human Rights Watch. Accessed at https://www.hrw.org/sites/default/files/report_pdf/bangladesh0818_ web2.pdf (January 26, 2021).

2018b. "Creating Panic." Human Rights Watch. Accessed at https:// www.hrw.org/sites/default/files/report_pdf/bangladesh1218_web.pdf (September 5, 2020).

2020a. "ASEAN: Overhaul Regional Response to Rohingya Crisis." Human

Rights Watch. Accessed at https://www.hrw.org/news/2020/06/26/aseanoverhaul-regional-response-rohingya-crisis (August 4, 2020).

2020b. "World Report 2020: Malaysia (Events of 2019)." Human Rights

Watch. Accessed at https://www.hrw.org/world-report/2020/countrychapters/malaysia\#5680cb (December 20, 2020).

. 2020c. "Malaysia: Stop Treating Rohingya Refugees as Criminals." Human Rights Watch (July 22). Accessed at https://www.hrw.org/news/2020/07/ 22/malaysia-stop-treating-rohingya-refugees-criminals (March 5, 2021).

Hutt, David. 2016. "Najib's Dangerous and Self-Serving Rohingya Campaign."

The Diplomat (December 24). Accessed at https:/thediplomat.com/ 2016/12/najibs-dangerous-and-self-serving-rohingya-campaign (October 30, 2020).

Idris, Iffat. 2017. "Rohingya refugee crisis: impact on Bangladeshi politics." $4 D$ Helpdesk Report 233 of Institute of Development Studies. 1-13.

Inter Sector Coordination Group (ISCG). 2017. "Bangladesh: Humanitarian Response Plan - Rohingya Refugee Crisis.” ISCG. Accessed at https:// reliefweb.int/report/bangladesh/bangladesh-humanitarian-responseplan-september-2017-february-2018-rohingya (September 18, 2020).

. 2019a. "Joint Response Plan for Rohingya Humanitarian Crisis - Final Report (March-December 2018).” ISCG. Accessed at https://reliefweb. int/report/bangladesh/bangladesh-humanitarian-response-plan-septe mber-2017-february-2018-rohingya (September 18, 2020).

2019b. "2019 Joint Response Plan for Rohingya Humanitarian Crisis." ISCG. Accessed at https://reliefweb.int/report/bangladesh/2019-jointresponse-plan-rohingya-humanitarian-crisis-january-december-enbn 
(September 18, 2020).

International Crisis Group. 2015. "Mapping Bangladesh's Political Crisis.” Asia Report N.264 of International Crisis Group. Accessed at https://www. refworld.org/pdfid/54eb265b4.pdf (September 26, 2020).

International Organization for Migration (IOM). 2017. "Readmission." IOM. Accessed at https://www.iom.int/sites/default/files/our_work/ODG/GCM/ IOM-Thematic-Paper-Readmission.pdf (December 1, 2020).

. 2020. "IOM Appeal: Humanitarian Support for Rohingya in Indonesia." IOM. Accessed at https://reliefweb.int/report/indonesia/iom-appealhumanitarian-support-rohingya-indonesia-25-june-2020-30-june-2021 (October 20, 2020).

International Republican Institute (IRI). 2018. "National Survey of Bangladesh Public Opinion.” IRI. Accessed at https://www.iri.org/sites/default/files/ september_2018_bangladesh_poll.pdf (September 5, 2020).

Ipsos. 2019. "World Refugee Day 2019: A Malaysian Perspective.” Ipsos. Accessed at https://www.ipsos.com/en-my/world-refugee-day-2019-malaysianperspective. (November 10, 2020).

Jacobsen, Karen. 2002. "Can Refugees Benefit the State? Refugee Resources and African State building.” Journal of Modern African Studies 40 (4), 577-96.

Jati, Irawan. 2017. "Comparative Study of the Roles of ASEAN and the Organization of Islamic Cooperation in Responding to the Rohingya Crisis." The Indonesian Journal of Southeast Asian Studies 1(1), 17-32.

Kaur, Amarjit. 2008. "International Migration and Governance in Malaysia: Policy and Performance." UNEAC Asia Papers 22, 4-18.

Kaur, Kiranjit. 2007. "Media reporting on refugees in Malaysia." University of New England Asia Center, Asia Papers 13, 8-12.

Kiragu, Esther, Angela Li Rosi, and Tim Morris. 2011. "States of denial: A review of UNHCR's response to the protracted situation of stateless Rohingya refugees in Bangladesh.” UNHCR Policy Development and Evaluation Service (PDES). Accessed at https://www.unhcr.org/4ee754c19.pdf (July 20, 2020).

Lemière, Sophie. 2018. "Inventing Malaysian Democracy: Najib's Tales and Stories." Harvard International Review 39(1), 39-44.

Lewa, Chris. 2001. "The Rohingya: Forced Migration and Statelessness.” Forced Migration in South Asian Region. Accessed at https://www.burmalibrary. org/sites/burmalibrary.org/files/obl/docs/Rohingya.F-M\%26Statelessne ss.htm\#_edn1 (August 20, 2020).

Lewis, David. 2019. "Humanitarianism, Civil Society and the Rohingya Refugee Crisis in Bangladesh.” Third World Quarterly 40 (10), 1884-1902. 
Loescher, Gil, and James Milner. 2009. "Understanding the Challenge.” Forced Migration Review, Protracted Displacement 33, 9-11.

Mathew, Penelope, and Tristan Harley. 2014. "Refugee Protection and Regional Cooperation in Southeast Asia." Fieldwork Report of the Australian National University. Accessed at https://openresearch-repository.anu. edu.au/ handle/1885/11662 (July 20, 2020).

McAuliffe, Marie, and Dinuk Jayasuriya. 2016. "Do asylum seekers and refugees choose destination countries? Evidence from large-scale surveys in Australia, Afghanistan, Bangladesh, Pakistan and Sri Lanka." International Migration 54 (4), 44-59.

Médecins Sans Frontières (MSF). 2019. "ASEAN should show true leadership on Rohingya, Myanmar." Médecins Sans Frontières. Accessed at https:// www.msf.org/general-assembly-asean-should-show-true-leadership-ro hingya (August 4, 2020).

Milton, Abul Hasnat, Mijanur Rahman, Sumaira Hussain, Charulata Jindal, Sushmita Choudhury, Shahnaz Akter, Shahana Ferdousi, Tafzila Akter Mouly, John Hall, and Jimmy T. Efird. 2017. "Trapped in statelessness: Rohingya refugees in Bangladesh." International journal of environmental research and public health 14 (8), 1-8.

Mostofa, Shafi M. D., and D. B. Subedi. 2020. "Rise of Competitive Authoritarianism in Bangladesh." Politics and Religion, 1-29.

Narine, Shaun. 2008. "Forty years of ASEAN: a historical review." The Pacific Review 21 (4), 411-429.

Ng, Eileen. 2018. "Malaysia intercepts boat carrying Rohingya refugees.” $A P$ News (April 3). Accessed at https://apnews.com/article/0b97687c533e4b0 39425553cf3c6e05d (March 4, 2021).

Ongpin, Patricia. 2008. "Refugees in Tanzania - Asset or Burden?" Journal of Development and Social Transformation 5, 37-8.

Paddock, Richard. 2016. "Tens of Thousands of Protesters Call for Najib Razak, Malaysian Leader, to Resign.” The New York Times (November 19). Accessed at https://www.nytimes.com/2016/11/20/world/asia/tens-ofthousands-of-protesters-call-for-najib-razak-malaysian-leader-to-resign. html (November 10, 2020).

Piromya, Kasit. 2020. "ASEAN Must Do More to Help the Rohingyas." The Diplomat (March 9). Accessed at https://thediplomat.com/2020/03/aseanmust-do-more-to-help-the-rohingyas (August 4, 2020).

Rashid, Muktadir. 2019. "63 People Held Since October." The New Age (January 15). Accessed at http://www.newagebd.net/article/61819/63-people-heldsince-october?fbclid=IwAR0dRY9-NJJnrUgd3QJxZe6DVUFkpdEGiKMM 
6OxK_fN2hsN2OD9di237bL8 (April 20, 2020).

Richmond, Anthony. 1993. "Reactive migration: Sociological perspectives on refugee movements." Journal of Refugee Studies 6(1), 7-24.

Rohmah, Ainur. 2017. "Indonesia sending humanitarian aid to Rohingya refugees." Anadolu Agency (AA)(August 13). Accessed at https://www.aa. com.tr/en/asia-pacific/indonesia-sending-humanitarian-aid-to-rohingy a-refugees/908815 (August 30, 2020).

Rutinwa, Bonaventure, and Khoti Kamanga. 2003. "The Impact of the Presence of Refugees in Northwestern Tanzania." Final Report of The Centre for Study of Forced Migration, University of Dar Es Salaam.

Rygiel, Kim, Feyzi Baban, and Suzan Ilcan. 2016. "The Syrian refugee crisis: The EU-Turkey 'deal' and temporary protection.” Global Social Policy 16(3), 315-320.

Safi, Michael, Oliver Holmes, and Redwan Ahmed. 2018. "Bangladesh PM Hasina wins thumping victory in elections opposition reject as farcical." The Guardian (December 31). Accessed at https://www.theguardian. com/world/2018/dec/30/bangladesh-election-polls-open-after-campaig n-marred-by-violence (October 26, 2020).

Sajjad, Tazreena. 2020. "As Bangladesh hosts over a million Rohingya refugees, a scholar explains what motivated the country to open up its borders." The Conversation (October 6). Accessed at https://theconversation.com/asbangladesh-hosts-over-a-million-rohingya-refugees-a-scholar-explainswhat-motivated-the-country-to-open-up-its-borders-133609 (November 30, 2020).

Siddiquee, Md Abu Bakar. 2019. "The portrayal of the Rohingya genocide and refugee crisis in the age of post-truth politics." Asian Journal of Comparative Politics 5(2), 89-103.

Siddiqui, Zeba, Krishna N. Das, and Ruma Paul. 2018. "Ahead of Bangladesh vote, opposition says it faces a reign of terror." Reuters (December 28).

Accessed at https://www.reuters.com/article/us-bangladesh-electionviolence-insight/ahead-of-bangladesh-vote-opposition-says-it-faces $\% 20$ a-reign-of-terror-idUSKCN1OR0KO (October 24, 2020).

Slothuus, Rune, and Claes H. de Vreese. 2010. "Political Parties, Motivated Reasoning, and Issue Framing Effects.” The Journal of Politics 72(3), 630645.

Sobhan, Raihan. 2017. "The case for an independent judiciary." Dhaka Tribune (August 13). Accessed at https://www.dhakatribune.com/opinion/2017/ 08/13/case-independent-judiciary(April 20, 2020).

Sonmez, Pelin, and Hikmet Kirik. 2017. "Turkish-EU Readmission Agreement: 
A Critique of EU-Turkey Migration Dialogue.” Security Strategies Journal 13 (25), 1-26.

Sukhani, Piya. 2020. "The Shifting Politics of Rohingya Refugees in Malaysia." The Diplomat (July 10). Accessed at https://thediplomat.com/2020/07/ the-shifting- politics-of-rohingya-refugees-in-malaysia (August 30, 2020).

Taylor, Edward, Mateusz Filipski, Mohamad Alloush, Anubhab Gupta, Ruben Irvin Rojas Valdes, and Ernesto Gonzalez-Estrada. 2016. "Economic impact of refugees." Proceedings of the National Academy of Sciences of the United States of America (PNAS) 113(27), 7449-7453.

The Guardian. 2015. "Malaysia and Thailand turn away hundreds on migrant boats." The Guardian (May 14). Accessed at https://www.theguardian. com/world/2015/may/14/malaysia-turns-back-migrant-boat-with-more-t han-500-aboard (July 10, 2020).

The Star. 2017. "Immigration and agencies to watch for Rohingya refugees." The Star (September 12). Accessed at https://www.thestar.com.my/news/ nation/2017/09/12/immigration-and-agencies-to-watch-for-rohingya-ref ugees (January 13, 2021). . 2021. Accessed at https://www.thestar.com.my (January 13, 2021).

UN High Commissioner for Refugees (UNHCR). 2013. "Back to where you once belonged. A historical review of UNHCR policy and practice on refugee repatriation." UNHCR Policy Development and Evaluation Service (PDES). Accessed at www.refworld.org/docid/5226d8f44.html (March 3, 2021).

. 2020a. "Figures at a Glance in Malaysia." UNHCR. Accessed at https:// www.unhcr.org/figures-at-a-glance-in-malaysia.html (September 20, 2020). 2020b. "Protection partner presence as of 31 October 2020." UNHCR. Accessed at https://data2.unhcr.org/en/documents/details/83063 (November $18,2020)$.

. 2020c. "UNHCR Bangladesh/Operational Update External.” UNHCR. Accessed at https://data2.unhcr.org/en/situations/myanmar_refugees. (November 1, 2020).

. 2020d. "UNHCR Viewpoint: 'Refugee' or 'migrant' - Which is right?" UNHCR. Accessed at https://www.unhcr.org/news/latest/2016/7/55df0e556/ unhcr-viewpoint-refugee-migrant-right.html (July 2, 2020).

. 2020e. "Joint statement on protection at sea in the Bay of Bengal and Andaman Sea." UNHCR. Accessed at https://www.unhcr.org/news/press/ 2020/5/5eb15b804/joint-statement-unhcr-iom-unodc-protection-sea-ba y-bengal-andaman-sea.html (November 10, 2020).

UN News. 2017. "UN human rights chief points to 'textbook example of ethnic 
cleansing' in Myanmar." UNNews (September 11). Accessed at https://news. un.org/en/story/2017/09/564622-un-human-rights-chief-pointstextbook-example-ethnic-cleansing-myanmar (July 12, 2020).

UN Office for the Coordination of Humanitarian Affairs (OCHA). 2020. "Financial Tracking Service (FTS) Bangladesh: Rohingya Refugee Crisis 2017." OCHA. Accessed at https://fts.unocha.org/appeals/628/donors? order=group_name\&sort=asc (June 10, 2020).

UN Office of the High Commissioner of Human Rights (OHCHR). 2021. "UN Treaty Body Database." OHCHR. Accessed at https://tbinternet.ohchr. org/_layouts/15/TreatyBodyExternal/countries.aspx (March 4, 2021).

Vas Dev, Sanjugta. 2003. "Asylum in Africa: The emergence of the 'reluctant host." Development 46(3), 113-118.

Wahab, Andika, and Aizat Khairi. 2019. "Moving onward: Transnationalism and factors influencing Rohingyas' migration from Bangladesh to Malaysia." Journal of Nusantara Studies 4(1), 49-68.

Waikar, Prashant, Mohamed Nawab Mohamed Osman, and Rashaad Ali. 2019. "Dancing with the Ummah: Islam in Malaysia's foreign policy under Najib Razak.” The Pacific Review, 1-29.

Welsh, Bridget. 2020. "Political Polarization in South and Southeast Asia: Old Divisions, New Dangers.” Report from Carnegie Endowment for International Peace, 41-52.

Whitaker, Beth. 1999. "Changing opportunities: Refugees and host communities in Western Tanzania." New Issues in Refugee Research Working Paper 11. Accessed at https://www.unhcr.org/3ae6a0c70.pdf (October 12, 2020). Yesmin, Sultana. 2016. "Policy towards Rohingya Refugees: A Comparative Analysis of Bangladesh, Malaysia, and Thailand." Journal of the Asiatic Society of Bangladesh 61(1), 71-100.

Yhome, Khriezo. 2018. "Examining India's Stance on the Rohingya Crisis." ORF Issue Brief 247, 1-16.

[Received Jan 31, 2021; Revised Mar 16, 2021; Accepted Mar 24, 2021] 